\title{
Snažil jsem se zachraňovat křest’anství, ale nešlo to. Osobní glosa ${ }^{1}$
}

\author{
Otakar A. Funda
}

FUNDA, 0. A.: I Had Been Trying to Save Christianity, but It Did Not Work. A Personal Gloss.

Philosophica Critica, vol. 3, 2017, no. 1, ISSN 1339-8970, pp. 67-71.

The text is a personal statement and a retrospective view of my own way as a philosopher and thinker. The first was the period of demythologisation and existential interpretation of the Christian faith. I had been trying to translate the message of the Gospel to the secular people for 20 years. However, it eventually turned out to be an honestly examined mistake. I have to confess today that the attitude was a subconscious attempt to save Christianity - to save it for myself. Finally, I went over to the attitude of critical rationalism and atheism, having found serious reasons to support these positions.

Key words: Demythologization - Critical Rationalism - Christianity Atheism - 0. A. Funda

Když bilancuji na konci života, čemu že jsem věnoval mnoho let - většinou vlastně promarněných - pak odvážím se povědět, že v letech 1961 - 1981 jsem se velmi vážně, opravdově a intelektuálně poctivě snažil zachraňovat křest'anství.

Již během studia na evangelické teologické fakultě mě oslovil projekt německého teologa Rudolfa Bultmanna, který lze označit jako projekt demytologizace a existenciální interpretace křest'anské víry. ${ }^{2}$ Bultmann byl přesvědčen, že mýtická mluva, kterou shodně se starověkým světem používá i Nový Zákon, nemá být současnému člověku předkládána předmětně k věření, nýbrž že mýtus je řád řeči, který se snaží o objektivizaci niterných existenciálních prožitků. Je tudíž možné položit i křest’anským mýtům otázku, co vypovídají o lidské existenci a místo mýtické světonázorové dogmatiky zvěstovat kerygma - zvěst nové existence.

1 Text vychádza so súhlasom autora na Slovensku, aj v Českej republike - na stránkach SOK - Sdružení pro levicovou teorii (www.sok.bz).

2 Blíže jsem později o Bultmannovi pojednal ve Filosofickém časopise (Funda 2002), tato studie je přetištěna ve sborníku Svědectví filosofie (Blecha 2009). 
Byl jsem tímto projektem osloven a snažil se jej adaptovat v českém evangelickém prostředí, a to nejen teologickým rozvíjením, ale i konkrétně každou neděli na kazatelně a při biblických výkladech v evangelickém sboru. Čímž jsem vzbudil nevoli mnoha pravověrných evangelíků. Většinou mimo moji farní obec. Ti, s nimiž jsem sdílel každodennost, záhy chápali, že mi jde o něco velmi vážného.

Byl jsem tehdy s Bultmannem přesvědčen, že nejde o strategický, podbízivý pokus přizpůsobit zvěst evangelia kritickému myšlení současného člověka, ale že z podstaty věci žije křest’anská zvěst - jak lze doložit již v různých vrstvách Nového Zákona - svou vždy novou interpretací. Pavlovy listy, deuteropavlovské listy, obecné epištoly, stejně tak jako odlišná kanonická evangelia předkládají odlišný christologický koncept, evangelia pak i odlišnou interpretaci Ježíšova příběhu.

Šel jsem ovšem za Bultmanna ještě o jeden radikální krok dál a inspirován Herbertem Braunem vztáhl projekt demytologizace i na samu kategorii Bůh. Došel jsem tak - v navázání na K. Jasperse - k tezi, že Bůh je šifra transcendence, kterou člověk ve svém životě zakouší jako to, „co si neříká sám, nýbrž co je mu do života řečeno“. Pověděno s H. Braunem: „jsem vyzván a jsem přijat“. Mytologický pojem Bůh je šifrou pro ono: „odkud vyzván a odkud přijat“. Bůh je tedy šifrou zcela jedinečné dimenze lidského života. Dimenze „svobody od sebe sama a otevřenosti pro ty druhé“. „Bůh děje se ve spolulidství".

Ještě mnohem, mnohem dříve, nežli jsem se dostal k četbě textů Hanse Alberta a jeho kritiky moderních teologů Rudolfa Bultmanna, Gerharda Ebelinga, a z katolické strany pak Hanse Künga a Josepha Ratzingera, došel jsem k prozření (1981), že protestantský pokus o existenciální interpretaci křest’anské víry je teologický sebeklam. Za sebe bych řekl: impozantní teologický sebeklam! Pravdu že tak vlastně mají orthodoxně ladění kritici Bultmanna, když mu vytýkají, že evangelium vyprázdnil, že jej zúžil jen do polohy filosofické reflexe lidské existence. Jestliže Bůh nejedná nadpřirozenými zásahy do lidského života a do dějin, jestliže tyto zásahy jsou mytologií, pak není důvod si myslet, že by mohl vstupovat do lidského života skrze transcendentní existenciální výzvu. Ve chvíli, když jsem řekl, že existenciální prožitek transcendence je výtvorem člověkova sebereflektivního vědomí, stal jsem se důvodně přesvědčeným ateistou. Pro svůj ateismus shledával jsem i další důvody, především ten, který je obsažen v dějinách náboženství a v samotných vrstvách biblických textů: Jestliže je evidentní, jak člověk postupně představu o Bohu či později představy o Kristu přetvářel, je nasnadě, že je i vytvořil.

Dvacet let, která jsem tedy věnoval snaze přetlumočit sekulárnímu člověku zvěst evangelia, se ukázala jako poctivě myšlený omyl. I když bych tehdy, když jsem stál na pozici demytologizace a existenciální interpretace křest’anské zvěsti odmítl názor, že se snažím zachraňovat křest’anství a tvrdil bych, že existenciální interpretace je z podstaty křest’anské zvěsti legitimní počin, dnes ve zpětném po- 
hledu nakonec připustím, že to vlastně byl podvědomý pokus křest’anství zachránit. A ptám se pro koho?

Tehdy jsem byl přesvědčen, že pro sekulárního člověka. Tomu však tato polovičatá demytologizace nedostačovala a vůbec jej nezajímala. Církevní křest’ané se k ní stavěli odmítavě. Pomohlo snad moje úsilí několika málo intelektuálně laděným jednotlivcům, kteří vyrostli v křest’anské tradici, nechtěli se s ní rozejít, a na druhé straně měli rozpaky věřit křest'anským dogmatům v orthodoxní podobě.

Z odstupu dalších let ale musím povědět, že jsem vlastně to celé úsilí oprostit křest'anskou zvěst od mýtických a supranaturálně metafysických představ a transformovat ji do podoby existenciální, dělal vlastně pro sebe. Snažil jsem se sám pro sebe zachránit křest’anství, v jehož tradici jsem vyrostl a jehož tradice jsem si vážil. Na druhé straně jsem věděl, že křest’anské věroučné výpovědi v orthodoxní podobě jsou pro mě nepřijatelné. Nebýt Bultmannova projektu, asi bych studia teologie zanechal. Projekt demytologizace a existenciální interpretace mi však umožnil nemuset se přetvařovat - a navíc mi poskytl zdání - tehdy jsem o tom byl hluboce přesvědčen - že interpretace evangelia současnému člověku je z podstaty evangelia samého legitimní počin.

Kdyby mi ovšem tehdy někdo řekl, že se angažuji pro existenciální interpretaci křest'anské víry z důvodu křest'anství zachránit, určitě bych to velmi vehementně odmítal a říkal, že mi jde o legitimní interpretaci křest’anské zvěsti, která od počátku je hermeneutickým dějstvím vždy nových interpretací. Tvrdil bych, že mi nejde o to křest’anství zachránit, nýbrž aktualizovat. Dnes, s odstupem, to hodnotím jinak.

Když se mi roku 1990 otevřela cesta na universitu, snažil jsem se kromě přednášek z filosofie ve svých religionistických přednáškách o konsekventně kritický, religionistický výklad vzniku křest’anství. Upozorňoval jsem na výšiny křest'anské antropologie, i když ji osobně z pozice kritického racionalismu nesdílím. V rámci své autentické dialektiky křest'anům křest'anství kritizuji a naopak zastánce zjednodušeného ateismu upozorňuji na výšiny křest’anské antropologie

Vezměme v úvahu ústřední křest’anské poselství, které je vyjádřeno velikonočními svátky. V klasickém pojetí je jeho obsah následující: Bůh poslal svého Syna, kterého svým Duchem zplodil z Marie panny, aby jeho Syn svou smrtí na křiži vykoupil svět, řečeno biblicky: „aby Bůh smíril svět sám se sebou, poslal svého Syna na kříž jako obět' smíření", (jako by to Bůh neuměl udělat jinak). Následně však svého Syna vzkřísil z mrtvých. A aby nevznikl problém, kde že ten vzkř́íšený Syn je a zda už nikdy více nezemře - nechal jej vystoupit na nebesa. $\mathrm{Nu}$, a aby to celé dějství dostalo zacelení, tak Kristus na konci věků opět přijde k poslednímu soudu. Hř́šnníci půjdou do zatracení, spravedliví do věčné blaženosti. (S tím ovšem měli teologové od počátku nesnáz - lítal v tom už Pavel: tak je poslední soud podle zásluh anebo podle milosti? Někteří vymysleli (Eirenaios) anakefaliósis ton panton - spasení všech. Augustin si vypomáhal absurdní představou vyvolení, 
Kalvín absurdní představou předurčení.) A aby ten Syn a Duch nebyli jen božími nástroji (manus Dei), vykonstruovali křest’anští bohoslovci v konci 3. a ve 4. století nauku o Trojici, že jsou to tři božské osoby - mia ousia, treis hypostaseis, nesmíšené a nerozdělené - nesmyslný konstrukt.

(Vznik islámu lze chápat jako pozdější náboženský pokus vrátit se k židovskému monotheismu, učinit z něho světové náboženství a překonat tak křest'anský rozpor mezi monotheismem a Trojicí.)

Ve srovnání s jinými velkými světovými náboženstvími - jednoduše monoteistickými, (židovství, islám), nebo zase s velkými náboženstvími Východu - princip brahma, nebo jing-jang nebo nadhled nirvány, je tento křest’anský velikonoční konglomerát představ sestaven z původně staroorientálních kultů (smírčí obět'), helenistických mysterií (vzkřrišení božstva) a židovské apokalyptiky (happy end dějin).

Co s tím, vždyt' je to nesmysl, poví střízlivě soudný člověk. (Tím neříkám, že by jiná velká světová náboženství nebyla také nesmyslem.)

Tyto nesmyslné křest'anské velikonoční představy se někteří teologové, patřil jsem k nim, pokoušeli překlenout a zachránit tím, že sice jasně řekli, že je to mytologie, ale že je třeba se ptát na její existenciálně-antropologické jádro. Např. představa smírčí oběti implikuje antropologii: „že někomu odpustit vlastně znamená vzít jeho vinu na sebe“, nebo „mýtická metafora vzkř́šení je šifrou naděje a existenciální proměny jednotlivého lidského života a i dějin“. Tak jsem to kdysi říkal a snažil se touto reinterpretací něco z intence těchto obskurních mýtů zachránit.

Jenže prvotní křest’ané - ani později většinové křest'anství na cestě svými dějinami až po současnost, tyto výpovědi a představy nechápalo a nechápe jako mýty a metafory, které nesou antropologicko-existenciální poselství (kerygma, nikoli dogma), nýbrž jako výpovědi o „skutečnostech nejskutečnějších, jiného řádu“, řečeno slovy velmi vzdělaného současného českého evangelického teologa světového formátu Petra Pokorného. (Jen za zavřenými dveřmi fakultní posluchárny, nikoli na kazatelně, připustí profesor P. Pokorný, že jsou to metafory, ale vzápětí dodá: „metafory, které vyjadřují objektivní realitu jiného řádu“.) Tyto tanečky teologických obezliček byly pro mne již od dob mých studií nepřijatelné. ${ }^{3}$

Od první poloviny osmdesátých let minulého století se mi stalo jasným, že když křest'anství, tak klasické, náboženské, supranaturální, metafysické - a když demytologizace a existenciální interpretace výpovědí a představ křest’anské víry, tak důsledná, tj. humanistická, ateistická. Jestliže je evidentní jak člověk v dějinách náboženství obsah představy a pojmu Boha přetvářel, je nasnadě že jej i vytvořil. Tím neříkám, že by Bůh byl vyřízené téma. Je to jeden z nejpozoruhodnějších lid-

3 Odkazem na profesora Petra Pokorného tak teprve po 20 letech reaguji na jeho útočně pokleslou polemiku (Pokorný 1996). 
ských výtvorů a stále otevřenou zůstává otázka, proč lidé představu Boha tvoří a jaké antropologické obsahy do této rétorické archetypální figury nažívají.

Velikonoce, 16. dubna, 2017

\section{Literatura}

BLECHA, I. (2009): Svědectví filosofie. Olomouc: Nakladatelství Olomouc.

FUNDA, A. O. (2002): Rudolf Bultmann - demytologizace a existenciální interpretace zvěsti křest’anské víry. In: Filosofický časopis, 50 (4), 615 - 638.

POKORNÝ, P. (1996): Běda našim dětem! In: Filosofický časopis 44 (6),1021-1025.

\section{O autorovi}

Profesor Otakar Funda (1943) pôsobil na Husitskej teologickej fakulte UK, Pedagogickej fakulte UK a Fakulte filozofickej Západočeskej univerzity v Plzni. Zároveň bol host'ujúcim profesorom na viacerých nemeckých univerzitách. Do češtiny preložil niektoré texty teológov A. Schweitzera a G. Ebelinga. Medzi jeho najvýznamnejšie práce z posledných rokov patria: Mezi vírou a racionalitou (2003), Ježíšs a mýtus o Kristu (2007), Když se rákos chvěje nad hladinou (2009), Racionalita verzus transcendence - Spor Hanse Alberta s moderními teology (2013). V roku 2015 vydala Karlova univerzita publikáciu Po cestách kritického myšlení (ed. J. Paitlová), ktorá sa v ôsmych príspevkoch zaoberá myslením Otakara Fundu. V časopise Philosophica Critica publikoval príspevok Racionalita a existence (č. 1, 2015). V roku 2016 autor publikoval vo Filosofickom časopise esej s náz-vom K filosofii náboženství. 